\title{
Disclosure Quality Measurement in the Public Sector: A Structured Literature Review
}

\author{
Marco Bisogno ${ }^{1}$, Francesca Citro ${ }^{1}$, Serena Santis ${ }^{1} \&$ Aurelio Tommasetti ${ }^{1}$ \\ ${ }^{1}$ Department of Management and Information Systems, University of Salerno, Salerno, Italy \\ Correspondence: Marco Bisogno, Department of Management and Innovation Systems, University of Salerno, \\ Via Giovanni Paolo II, 132, 84084, Fisciano (SA), Italy. Tel: 0039-089-963-148. E-mail: mbisogno@unisa.it
}

Received: October 5, 2017

Accepted: November 8, 2017

Online Published: November 20, 2017

doi:10.5539/ijbm.v12n12p119

URL: https://doi.org/10.5539/ijbm.v12n12p119

\begin{abstract}
The study investigates previous research concerning disclosure quality measurement in the public sector context. The principal motivation for undertaking this analysis is the growing body of literature that has examined this issue from different perspectives in light of the increasing attention paid by academics and practitioners to the transparency and accountability of public sector entities. The study adopts a structured research methodology, aiming to offer a critical overview of the state of the art, highlighting the main issues investigated by scholars and the areas of research which are under-investigated, unveiling emerging gaps. In so doing, this study outlines a future research agenda.
\end{abstract}

Keywords: disclosure quality, public sector, structured literature review

\section{Introduction}

Reforms implemented in several countries under the new public financial management and the new public governance paradigms have accentuated the importance of both the efficiency and effectiveness of public service delivery. An essential part of this process is to disclose adequate and reliable information guaranteeing open access to documents held by public sector entities. Many countries have implemented Freedom of Information Acts, according to which public authorities are required to disclose specific data regarding their activities. In addition, citizens and other stakeholders are entitled to request information from public authorities. Accordingly, increasing attention to disclosure measurement in the public sector can be observed because of the growing emphasis and focus on the transparency and accountability (Steccolini, 2004) of public sector organizations.

This study aims to provide a structured literature review concerning disclosure quality (DQ) in the public sector, to understand how DQ measurement is evolving and to offer critically an overview of the state of the art in the public sector, drawing implications for scholars and policymakers and outlining a future research agenda. The reason for this review is fundamentally the lack of focus on DQ in the public sector. Compared to the private sector, only a few studies have investigated this issue in the public sector and there has been no comprehensive structured literature review on the topic published in academic journals. Even if this does not identify a research gap, it underlines that there is a need to systematize previous studies to understand how DQ measurement is evolving in the public sector context. As a consequence, critically reviewing the models and frameworks proposed, as well as determinants adopted in previous studies in measuring the disclosure level, can add fresh light on the topic in the wake of the growing relevance of transparency.

This paper adopts a structured literature review (SLR) methodology as developed by Guthrie, Ricceri, and Dumay (2012), Massaro, Dumay, and Garlatti (2015), Massaro, Dumay, and Guthrie (2016) and Dumay, Bernardi, Guthrie, and Demartini (2016). According to Dixon-Woods (2011, p. 331) "researchers use SLRs to map and assess the existing intellectual territory to identify future research needs". The main advantage of an SLR is its empirical grounding, avoiding criticism that seminal articles may be missed and eliminating most researcher bias (Tranfield, Denyer, \& Smart, 2003, p. 209). The results and implications should inform practitioners and academics about the main evolution of DQ in the public sector, identifying future research needs.

According to Alvesson and Deetz's (2000, pp. 17-20) framework, based on three critical research tasks, namely "insight", "critique" and "transformative redefinitions", this SLR aims to answer the following research 
questions:

RQ1. How is disclosure quality measurement literature in the public sector developing?

$\mathrm{RQ} 2$. What is the focus and critique of disclosure quality measurement within the public sector?

RQ3. What is the future of disclosure quality measurement within the public sector?

The remainder of the paper is organized in three sections. Section 2 describes the methodology used to investigate research on DQ measurement in the public sector. Section 3 provides insights and a critique. The final section offers several arguments concerning the future of research on DQ measurement in the public sector in relation to practice and policy and presents several unanswered research questions.

\section{Methodology}

A literature review is a research method attuned to reconnecting knowledge from the past with future directions of studies that can be used to examine theories, or as a basis for intervention, or to summarize particular issues (Petticrew \& Roberts, 2008; Tranfield et al., 2003). The literature review has evolved in recent years due to the development of different approaches and the support of informatics in literature database analysis. Massaro et al. (2016, p. 769) have identified a "literature review continuum", ranging from a rapid review (essentially a review done subjectively, with no rules) to a structured literature review (characterized by the application of specific rules). The second approach means going beyond a mere synthesis and interpretation of previous contributions, being based on a written protocol that describes the source of information, supporting tools and the primary data sought from the papers.

Having already defined the research questions of this study, developing the SLR requires several other steps, illustrated in the following sections.

\subsection{Literature Search}

Several selection criteria were identified to select the eligible literature for our research objectives. First, we searched for articles published in academic journals with a peer-reviewed evaluation process, written in English. Second, to ensure substantive relevance of the potential articles, we referred to three databases (Scopus, Web of Science and Business Source Complete - EBSCO), searching for the following keywords in the title, abstract or keywords of the article: (disclosure quality measurement) OR (disclosure indices) OR (disclosure determinant analysis) OR (disclosure level evaluation). We adopted several limitations (research domain: social science; research areas: business economics and public administration; language: English; peer reviewed journals).

The third step consisted of reading all abstracts of the selected articles, checking for a discussion related to DQ, the main focus being to assess the relevance of the articles for the review. Therefore, having identified any duplicates (i.e. the same article included in more than one database), we adopted several exclusion criteria:

- First, we read the abstracts, in some cases the full content of the articles, to identify those addressing DQ in ambiguous terms or relating to other fields (such as disclosure of nutrition information on food labels; energy consumption disclosure requirements; sustainability index on the responsible use of water; disclosure of the Internet marketplace). More concretely, we excluded 49 articles as they dealt with DQ ambiguously or used the term in a general or unrelated way.

- Second, we excluded 573 articles concerning DQ in the private sector context. We adopted broad keywords as we aimed to capture as many articles as possible, reducing the potential risk of losing relevant articles, especially those focused on private firms controlled by public sector entities. Furthermore, we aimed to identify the potential number of papers related to DQ measurement concerning the private sector, for comparison with the number of articles focused on the public sector.

As a result, we identified 30 articles focusing on DQ measurement in the public sector. We used 1 January 1986 as a starting date as no articles on DQ measurement in the public sector were identified before this date. We adopted a cut-off date of 30 October 2016. We then downloaded the PDF versions of these articles and stored them in a Mendeley database with full referencing details. Table 1 gives an overview of the results of this process, while the Appendix provides a complete list of the papers selected for this review. 
Table 1. Database search results

\begin{tabular}{|c|c|c|c|c|}
\hline & Scopus & Web of science & Ebsco & Total \\
\hline Selected articles & 452 & 263 & 160 & 875 \\
\hline No. of total duplicates & & & & $(223)$ \\
\hline After deleting duplicates & & & & 652 \\
\hline No. of papers concerning other fields & & & & $(49)$ \\
\hline No. of paper about DQ in private sector & & & & $(573)$ \\
\hline No. of paper about DQ in public sector & & & & 30 \\
\hline
\end{tabular}

Search limiters: Only academic journals in English.

The vast majority of the papers investigated DQ issues in the private sector context, while few focused on public sector entities despite the recent growing relevance of transparency issues. However, we comment on this result more extensively by considering the years of publication of the selected articles.

Table 2 illustrates that, albeit with some exceptions, articles on DQ measurement in the public sector have been published in journals within different thematic areas, which means that this topic has been investigated from different perspectives, adopting different theoretical and methodological approaches.

Table 2. Classification of articles by journal

\begin{tabular}{|c|c|c|c|}
\hline Code & Journal name & No & $\%$ \\
\hline SRJ & Social Responsibility Journal & 1 & 3.33 \\
\hline AJBA & Asian Journal of Business \& Accounting & 1 & 3.33 \\
\hline PM\&M & Public Money \& Management & 1 & 3.33 \\
\hline GBER & Global Business and Economics Review & 1 & 3.33 \\
\hline AP & Accounting Perspectives & 1 & 3.33 \\
\hline EM & Ekonomie a Management & 1 & 3.33 \\
\hline PAR & Pacific Accounting Review & 2 & 6.67 \\
\hline BAR & British Accounting Review & 1 & 3.33 \\
\hline $\mathrm{A} \& \mathrm{~F}$ & Accounting \& Finance & 1 & 3.33 \\
\hline TRAS & Transylvanian Review of Administrative Sciences & 1 & 3.33 \\
\hline IJPSM & International Journal of Public Sector Management & 1 & 3.33 \\
\hline JAPP & Journal of Accounting and Public Policy & 4 & 13.33 \\
\hline SEAJ & Social and Environmental Accountability Journal & 1 & 3.33 \\
\hline MFJ & Municipal Finance Journal & 1 & 3.33 \\
\hline HBR & Harvard Business Review & 1 & 3.33 \\
\hline JAAR & Journal of Applied Accounting Research & 1 & 3.33 \\
\hline JES & Journal of Economic Studies & 1 & 3.33 \\
\hline $\mathrm{AF}$ & Accounting Forum & 2 & 6.67 \\
\hline IJF & Indian Journal of Finance & 1 & 3.33 \\
\hline JFC & Journal of Financial Crime & 1 & 3.33 \\
\hline JPSM & Journal of Purchasing and Supply Management & 1 & 3.33 \\
\hline JAR & Journal of Accounting Research & 1 & 3.33 \\
\hline LHS & Leadership in Health Services & 1 & 3.33 \\
\hline JIC & Journal of Intellectual Capital & 1 & 3.33 \\
\hline \multirow[t]{2}{*}{ TFSC } & Technological Forecasting and Social Change & 1 & 3.33 \\
\hline & Totals & 30 & 100 \\
\hline
\end{tabular}

Analysing the evolution of articles on DQ measurement within the public sector (see Figure 1), the results show an increase in the last decade. The literature search identified 30 relevant articles $73 \%$ of which were published after 2010, suggesting a growing trend. Some of the most recent articles are those of Abu Bakar and Saleh (2015), Allini, Manes Rossi, and Hussainey (2016) and Araújo and Tejedo-Romero (2016). Some of the oldest are Robbins and Austin (1986), Giroux (1989) and Herzlinger (1996). 


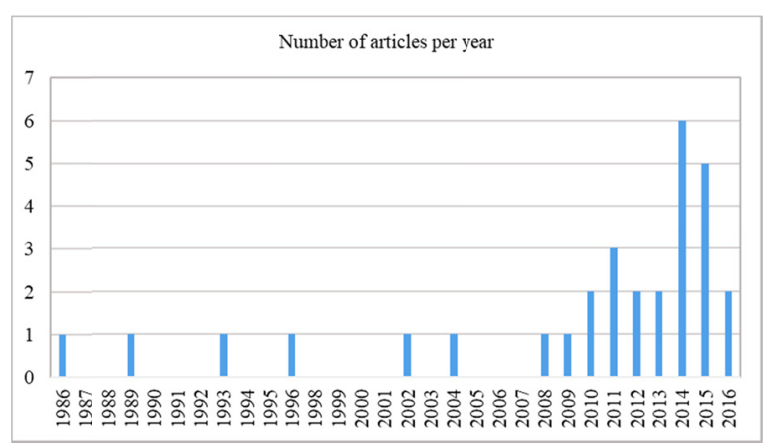

\subsection{Article Impact}

Figure 1. Number of articles by year

Massaro et al. (2016) highlight that citation metrics allow researchers to understand how literature in a field is developing by examining the impact that different articles have over time. In addition, researchers using these measures can understand how and if the field under review is important. Consistently, this step involves determining the impact of articles, expressed through the number of Google Scholar citations. According to Dumay (2014, p. 5), Google Scholar is "considered a leading tool in citation analysis" and it has been used to measure article impact in previous studies in accounting.

We downloaded from Google Scholar the citation data of the articles as of 26 April 2017. Considering that older articles can accumulate more citations compared to more recent articles, we show two separate rankings to avoid bias (Dumay et al., 2016). Therefore, we use total citations and average citations per year (CPY) to analyse the impact of DQ measurement in public sector research. Table 3 shows the top 10 articles by citation and Table 4 shows the top 10 articles by CPY (Note 1 ).

Table 3. Top 10 articles by Google Scholar citations (as at 26 April 2017)

\begin{tabular}{|c|c|c|c|}
\hline No & References & Articles & Cit. \\
\hline 1 & Herzlinger (1996) & Can Public Trust in Nonprofits Governments Be Restored? & 273 \\
\hline 2 & Robbins, \& Austin (1986) & $\begin{array}{l}\text { Disclosure Quality in Governmental Financial Reports: An Assessment of the } \\
\text { Appropriateness of a Compound Measure }\end{array}$ & 234 \\
\hline 3 & Coy\& Dixon (2004) & $\begin{array}{l}\text { The Public Accountability Index: Crafting a Parametric Disclosure Index for } \\
\text { Annual Reports }\end{array}$ & 168 \\
\hline 4 & Schneider \& Samkin (2008) & Intellectual Capital Reporting by the New Zealand Local Government Sector & 105 \\
\hline 5 & $\begin{array}{l}\text { Gordon, Fischer, Malone \& Tower } \\
\text { (2002) }\end{array}$ & $\begin{array}{l}\text { A comparative empirical examination of extent of disclosure by private and } \\
\text { public colleges and universities in the United States }\end{array}$ & 98 \\
\hline 6 & Coy, Tower, \& Dixon (1993) & Quantifying the Quality of Tertiary Education Annual Reports & 95 \\
\hline 7 & Giroux (1989) & Political Interests and Governmental Accounting Disclosure & 93 \\
\hline 8 & Corina \& Taplin (2011) & The Measurement of Sustainability Disclosure: Abundance versus Occurrence & 63 \\
\hline 9 & Lynch (2010) & $\begin{array}{l}\text { An Examination of Environmental Reporting by Australian State Government } \\
\text { Departments }\end{array}$ & 39 \\
\hline 10 & $\begin{array}{l}\text { Abd Rahman, Mohamed Zain, \& } \\
\text { Yahaya Al-Haj (2011) }\end{array}$ & $\begin{array}{l}\text { CSR Disclosures and Its Determinants: Evidence from Malaysianı Government } \\
\text { Link Companies }\end{array}$ & 35 \\
\hline
\end{tabular}

Table 4. Top 10 articles by citation per year (CPY) (as at 26 April 2017)

\begin{tabular}{|c|c|c|c|}
\hline No & References & Articles & $C P Y$ \\
\hline 1 & Coy \& Dixon (2004) & $\begin{array}{l}\text { The Public Accountability Index: Crafting a Parametric Disclosure Index for } \\
\text { Annual Reports }\end{array}$ & 12.92 \\
\hline 2 & Herzlinger (1996) & Can Public Trust in Nonprofits Governments Be Restored? & 12.41 \\
\hline 3 & Schneider \& Samkin (2008) & $\begin{array}{l}\text { Intellectual Capital Reporting by the New Zealand Local Government } \\
\text { Sector }\end{array}$ & 11.67 \\
\hline 4 & Corina \& Taplin (2011) & $\begin{array}{l}\text { The Measurement of Sustainability Disclosure: Abundance versus } \\
\text { Occurrence }\end{array}$ & 10.5 \\
\hline 5 & Robbins \& Austin (1986) & $\begin{array}{l}\text { Disclosure Quality in Governmental Financial Reports: An Assessment of } \\
\text { the Appropriateness of a Compound Measure }\end{array}$ & 7.55 \\
\hline
\end{tabular}




\begin{tabular}{lll}
\hline 6 & $\begin{array}{l}\text { Gordon, Fischer, Malone, \& Tower } \\
\text { (2002) }\end{array}$ & $\begin{array}{l}\text { A comparative empirical examination of extent of disclosure by private and } \\
\text { public colleges and universities in the United States }\end{array}$ \\
7 Abd Rahman, Mohamed Zain \& & $\begin{array}{l}\text { CSR Disclosures and Its Determinants: Evidence from Malaysian } \\
\text { Government Link Companies }\end{array}$ \\
Yahaya Al-Haj (2011) & An Examination of Environmental Reporting by Australian State \\
& Gynch (2010) & $\begin{array}{l}\text { Government Departments } \\
\text { Quantifying the Quality of Tertiary Education Annual Reports }\end{array}$ \\
9 Coy, Tower, \& Dixon (1993) & Political Interests and Governmental Accounting Disclosure \\
\hline
\end{tabular}

The articles by Herzlinger (1996), Robbins and Austin (1986), Coy and Dixon (2004) and Schneider and Samkin (2008) are the most highly cited, making them a must read for any scholar exploring DQ measurement in the public sector. Interestingly, the 10 most cited articles are both in the list of the papers with the highest CPY and $\mathrm{CI}$; therefore, there is a strong interest among scholars to cite the oldest research that represents strong pillars for DQ measurement within the public sector. Four (40\%) of these papers focused on the United States (US) context (Robbins \& Austin, 1986; Giroux, 1989; Gordon, Fischer, Malone, \& Tower, 2002; Herzlinger, 1996), three $(30 \%)$ on New Zealand (Coy \& Dixon, 2004; Coy, Tower, \& Dixon, 1993; Schneider \& Samkin, 2008) and two (20\%) on the Malaysia (Abd Rahman, Mohamed Zain, \& Yahaya Al-Haj, 2011; Joseph \& Taplin, 2011). Only one paper $(10 \%)$ focused on the Australian context (Lynch, 2010). Therefore, the results show a high concentration regarding the geographical area analysed; the US and New Zealand are the most investigated contexts.

Analysing the specific topic of these studies, it is worth noting that three papers focus on accounting disclosure (Robbins \& Austin, 1986; Giroux, 1989; Herzlinger, 1996); three articles focus on the quality of service performance reporting in higher education reports (Coy \& Dixon, 2004; Coy et al., 1993; Gordon et al., 2002); three papers focus on corporate social responsibility (CSR) and environmental reporting issues within state government departments (Lynch, 2010), local governments (Joseph \& Taplin, 2011) and government business enterprise (Abd Rahman et al., 2011). Therefore, the research covers a wide range regarding the topic developed; in particular, the oldest articles deal with financial disclosure or the quality of service performance reporting, while the most recent papers focus on CSR and environmental reporting issues.

\subsection{Developing an Analytical Framework}

The coding framework developed by Guthrie et al. (2012) and Dumay et al. (2016) was modified to serve our topic, as Table 5 illustrates.

Table 5. Results of analysis of DQ in the public sector

\begin{tabular}{|c|c|c|c|c|c|c|}
\hline A. & Government Jurisdiction & No. & $\% B$. & Country of research & No. & $\%$ \\
\hline A1 & Supra-National/International/Comparative & 2 & $6.7 \mathrm{~B} 1$ & US/Canada & 9 & 30.0 \\
\hline $\mathrm{A} 2$ & National & 0 & $0,0 \mathrm{~B} 2$ & Australasia & 12 & 40.0 \\
\hline A3 & State/Territory/Province & 3 & $10.0 \mathrm{~B} 3$ & Europe & 7 & 23.3 \\
\hline A4 & Local/Municipal & 11 & $36.6 \mathrm{~B} 4$ & Africa & 1 & 3.3 \\
\hline A5 & Public Institutional System & 7 & $23.3 \mathrm{~B} 5$ & Other & 1 & 3.3 \\
\hline A6 & Public Business Enterprise & 5 & 16.7 & Totals & 30 & 100.0 \\
\hline C. & Focus of the article & No. & $\% D$. & Research methods & \multicolumn{2}{|c|}{ No. \% } \\
\hline $\mathrm{C} 1$ & External reporting/financial information & 10 & $33.3 \mathrm{D} 1$ & Case/Field study/Interviews & 0 & 0.0 \\
\hline $\mathrm{C} 2$ & External reporting/non-financial information & 10 & $33.3 \mathrm{D} 2$ & Content analysis/Historical analysis & 8 & 26.7 \\
\hline $\mathrm{C} 3$ & Auditing & 0 & $0,0 \mathrm{D} 3$ & Survey/Questionnaire/Other empirical & 20 & 66.7 \\
\hline $\mathrm{C} 4$ & Accountability and governance & 4 & $13.4 \mathrm{D} 4$ & Commentary/Normative/Policy & 1 & 3.3 \\
\hline E. & DQ frameworks and models & No. & $\%$ & & & \\
\hline E1 & None proposed & 4 & 13.33 & & & \\
\hline E2 & Applies or considers previous & 16 & 53.33 & & & \\
\hline E3 & Proposes a new & 10 & 30.33 & & & \\
\hline & Totals & 30 & 100.0 & & & \\
\hline
\end{tabular}


First, we based the "Jurisdiction" criterion on different government levels rather than the broader organizational types, as in Broadbent and Guthrie (2008) (see section 3.1). Second, we did not consider the "Organizational focus" category because our research was focused on the "Public sector" attribute; therefore, it was no longer needed. Finally, as we expected a widespread focus on external reporting disclosure, we introduced more detailed categories, distinguishing the following: $\mathrm{C} 1$ : External reporting - financial information; $\mathrm{C} 2$ : External reporting - non-financial information, which includes disclosure of social responsibility, disclosure on environmental issues, disclosure on intellectual capital (IC) and so on. We did not modify the other criteria. We detail these changes, additions and deletions before discussing the results developed from the analysis of each criterion in the third section that follows.

\subsection{Developing Reliability and Article Coding}

This step involved checking the reliability of the adopted framework. Several meetings were organized between the authors to define the criteria to be applied in selecting the articles and assessing their pertinence. Further discussion between the authors clarified issues related to the classification of the articles, resolving any discrepancies. More concretely, three members of the research team coded the articles, recording the results in an Excel spreadsheet, before discussing any uncertainties with the fourth author to clarify the coding. Having shared all the decisions step by step, the authors did not carry out formal reliability checking, such as those based on Krippendorff's (2013) alpha, as they did not deem it necessary.

\section{Insights and Critique}

This section aims to answer RQ1 "How is disclosure quality measurement literature in the public sector developing?" and RQ2 "What is the focus and critique of disclosure quality measurement in the public sector literature?", bearing in mind the results of Table 5.

\subsection{Jurisdiction}

To develop the list of attributes concerning the Jurisdiction (A) criterion, the original list proposed by Broadbent and Guthrie (2008, p. 140) was adapted. First, we employed different governmental levels, including a supranational/international context (A1), which covered comparative papers or a cross-national boundary organization (e.g. the European Union [EU]), as well as the various tiers of government within a national setting: national (A2), state/territory/province (A3) and local/municipal (A4). Second, following Broadbent and Guthrie (1992), public institutional systems (PISs) and public business enterprises (PBEs) were also identified as relevant elements of the domain of the public sector because they provide public services, albeit in different ways. Therefore, we added "A5: PIS" to include central public services, such as healthcare and education, and "A6: PBE" to include companies delivering public services with a public sector entity as a major shareholder.

As Table 5 shows, the "A4: local/municipal" and "A5: PIS" categories (11 and 7 articles, respectively) are the two most popular areas of interest. Moreover, when coding the articles in the "A5: PIS" category, we observe that six papers are focused on universities (e.g. Condie, Dunmore, \& Dunstan et al., 2013; Coy \& Dixon, 2004) and one refers to healthcare structures in Morocco (Sahel, DeBrouwere, Dujardin, Kegels, Belkaab, \& Belghiti, 2015).

In addition, the "A6: PBE" level is investigated to a considerable extent (five papers), while articles focusing on "A1: supra-national/international/comparative" category are not abundant (only two); they are at the supra-national level, referring to a sample of EU member state countries (Krambia-Kapardis, 2014) and Eurozone countries (de Deus \& de Mendonça, 2015).

Regarding the "A3: state/territory/province" category, one study focuses on the state government level (the case of an Australian government department) and two articles adopt a regional perspective (the case of Cine province government and the case of Orange County in the US). Surprisingly, there are no papers at the "A2: national" level.

The prevalent focus on local government level may be due to the growing attention of citizens about information provided by their municipality. Transparency and accountability, while being general concepts to be referred to all kinds of public administrations, seem to be more relevant in the case of local governments (Steccolini, 2004). Additionally, it is worthy that several papers focus on DQ of universities. This result relies on the increasingly competitive environment, where universities are required to build up and preserve a distinct image to gain a competitive advantage (Paramewaran \& Glowacka, 1995) when recruiting students and obtaining funds (Murias, de Miguel \& Rodríguez, 2008). As a consequence, providing stakeholders with adequate and reliable information is considered pivotal in current times (Bisogno, Citro \& Tommasetti, 2014), since it helps to improve transparency and, more broadly, the quality of services provided to stakeholders. 


\subsection{Country of Research}

The second criterion is the country of research (Guthrie et al., 2012). This is divided into six regions, these being: B1: US/Canada; B2: Australasia, including Australia, New Zealand and parts of Asia, such as China, India, Malaysia, Singapore, Thailand, Japan, etc.; B3: Europe; B4: Africa; B5: other. If the regional focus or the geographical location of the research cannot be determined, we use the country of the first author.

We find that Australasia is the most active region with 12 articles (e.g. Lynch, 2010; Schneider \& Samkin, 2008), followed by the US/Canada with 9 (e.g., Blanco, Lennard, \& Lamontagne, 2011; Fischer, Gordon, \& Kraut, 2010). Compared with other regions, Europe as a research site is less investigated with only seven articles (e.g. Araújo \& Tejedo-Romero, 2016; Bisogno, Citro, \& Tommasetti, 2014). Finally, Africa and other sites contribute little to DQ measurement in public sector research. The paper from Africa provides a narrative literature review concerning factors influencing public sector disclosure (Abu Bakar \& Saleh, 2015); while the article from another site analyses the implementation of quality improvement intervention for health services in Morocco (Sahel et al., 2015).

In summary, the results show a high concentration regarding the geographical area analysed; Australasia and US are the context most investigated.

In some cases (such as New Zealand, India and Malaysia), this may be the result of active policies in these countries aimed at promoting the rapid development and diffusion of the sustainability concept and accountability mechanisms. This has resulted from deliberations on sustainable development in the 2000s and increasing pressure for more information, accountability and transparency with regard to CSR and environmental disclosure. For instance, the Putrajaya Committee on the high-performance government-linked company (GLC) in Malaysia is leading an intensive programme to promote a set of guidelines (The Silver Book) on how GLCs can responsibly contribute to society, thus creating a positive impact on business and society. As Abd Rahman et al. (2011, p. 186) note, "The Putrajaya Committee's aspiration is that GLCs will lead corporate Malaysia in demonstrating how businesses should contribute in a socially responsible, sustainable and meaningful way while gaining benefits for themselves".

A side effect is a growing number of studies focused on the same area, while other areas of the world are almost ignored (e.g. Africa). However, we would critically argue that investigating different contexts could improve our knowledge of the field, also from a comparative perspective.

\subsection{Focus of DQ Measurement in the Public Sector Literature}

The third criterion is "C: Focus of DQ measurement in the public sector", consisting of six attributes: $\mathrm{C}$ : external reporting - financial information; $\mathrm{C} 2$ : external reporting - non-financial information; $\mathrm{C} 3$ : auditing; $\mathrm{C} 4$ : accountability and governance; C5: management control/strategy; C6: performance measurement; C7 other, albeit we cannot code the articles to the first five attributes.

The most popular categories concern disclosure of external reporting ( $\mathrm{C} 1$ and $\mathrm{C} 2)$ with 20 articles. This result was anticipated as external reporting is considered an essential vehicle for disclosure. Indeed, public sector entities can provide information through different means, such as annual reports, conference calls, management commentary, management discussion and analysis, etc.; some of these are mandatory, while others are provided on a voluntary basis.

Moreover, four papers focus on accountability and governance (C4) (Bisogno et al., 2014; Herzlinger, 1996; Hooks, Tooley, \& Basnan, 2014; Krambia-Kapardis, 2014), only one article concerns performance measurement (C6) (Sahel et al., 2015), while five articles concentrate on other (C7) topics (Abu Bakar \& Saleh, 2015; Araújo \& Tejedo-Romero, 2016; Deaconu \& Nistor, 2014; Joseph \& Taplin, 2011; Yu, 2014). Finally, we observe that there are no published articles on auditing (C3) or management control strategy (C5).

Further insights and a critique on the "focus of the article" are presented in the following sub-sections.

\subsubsection{External Reporting: Disclosure of Financial Information}

As to the " $\mathrm{C} 1$ : external reporting - financial information" category, ten papers have investigated the level of disclosure of accounting information published in annual reports.

Seven articles considered one or more sections of the annual report (Allini et al., 2016; Blanco et al., 2011; de Deus \& de Mendonça, 2015; Fischer et al., 2010; Guo, Fink, \& Frank, 2009; Kaur \& Arora, 2013; Robbins \& Austin, 1986); while three papers concern specific issues such as disclosure regarding single financial statements' items (Bunget, Blidisel, Feleaga, \& Popa, 2014; Giroux, 1989; Vermeer, Styles, \& Patton, 2012). Five of these studies (Allini et al., 2016; de Deus \& de Mendonça, 2015; Kaur \& Arora, 2013; Robbins \& Austin, 1986; 
Vermeer et al., 2012) also concentrate on the analysis of disclosure determinants, investigating the reasons why some entities disclose more or less information than others.

In this field of study, only two old contributions are highly cited (Giroux, 1989; Robbins \& Austin, 1986). Robbins and Austin (1986) provides the first study assessing the sensitivity of DQ test determinants in municipal annual reports to the use of a compound measure, instead of a unidimensional (simple) measure. Giroux (1989) tests public choice theory in the context of financial disclosure in a municipal setting. In this paper, the disclosure indexes of municipalities are developed on the basis of the anticipated needs of political groups. Next, DQ relationships are modelled based on the political and economic incentives of the groups actively involved in the governmental processes of municipalities. The results suggest that each group with political power will have only limited influence on DQ.

Articles included in this category can also be distinguished considering their main aim. While several articles focus on disclosure measurement by examining financial statements or particular items, others investigate the determinants. Table 6 summarizes the relevant literature related to this kind of disclosure, highlighting a granular look at the research context, some disclosure aspects, the main documents analysed and the determinant analyses conducted by each study.

\subsubsection{External Reporting: Disclosure of Non-Financial Information}

As to the "C2: external reporting - non-financial information" category, seven articles concern social responsibility disclosure, two papers address environmental disclosure practices and one paper is related to IC disclosure.

In terms of social responsibility disclosure, two papers discuss the quality of service performance reporting among New Zealand universities (Coy \& Dixon; 2004; Coy et al., 1993), while two papers focus on the quality of the presentation of non-financial information in the statement of service performance (SSP) for New Zealand universities (Condie et al., 2013) and New Zealand local authorities (Keerasuntonpong, Dunstan, \& Khanna et al., 2015).

Moreover, one study focuses on service efforts and accomplishment (SEA) disclosures in higher education institutions (Gordon et al., 2002) and one paper investigates the level of CSR disclosure in a sample of Malaysian government-linked companies (Abd Rahman et al., 2011). Finally, one paper (Mansi, 2015) explores sustainable procurement (SP) practices across central public sector enterprises (CPSEs) in India.

In this field of study, four contributions are highly cited papers (Abd Rahman et al., 2011; Coy \& Dixon, 2004; Coy et al., 1993; Gordon et al., 2002). Coy et al. (1993) and Coy and Dixon (2004) discuss the quality of service performance reporting of New Zealand universities. These studies identify three broad categories of disclosure, namely: overview, financial and service disclosures. They then subdivide them to for eight specific sub-categories, among which are teaching, research and community service items. Gordon et al. (2002) provide the first comprehensive study of the extent of college and university disclosure by US institutions of higher education. This includes both public and private institutions and hypothesizes a difference in motivations for disclosure between the two categories, mainly concerning SEA disclosures. Finally, Abd Rahman et al. (2011) investigate the level of CSR disclosure of a sample of Malaysian government-linked companies to observe the relationship between CSR disclosure practices and several company characteristics in the Malaysian scenario. The four significant disclosure themes are the human resource aspect, socially-oriented activities, the marketplace aspect and environmental information.

In terms of environmental disclosure practices, two articles (Freedman \& Park, 2013; Lynch, 2010) focus on environmental reporting. One (Lynch, 2010) is a highly cited recent paper and it examines environmental voluntary disclosure practices within the annual reports produced by a sample of Australian state government departments through a new type of environmental disclosure index. The primary focal areas of the disclosure are environmental programmes and environmental performance indicators (such energy, water, biodiversity, emissions, effluents and waste, etc.). 
Table 6. Summary of literature review on the disclosure of financial information

\begin{tabular}{|c|c|c|c|c|c|}
\hline \multirow{2}{*}{ Authors } & \multirow{2}{*}{ Context } & \multirow{2}{*}{ Disclosure aspect } & \multicolumn{2}{|c|}{ Disclosure level } & \multirow{2}{*}{ Determinants in analysis } \\
\hline & & & General & Specific items & \\
\hline $\begin{array}{l}\text { Robbins and } \\
\text { Austin } \\
(1986)\end{array}$ & $\begin{array}{l}\text { Chicago, Boston, } \\
\text { New York and } \\
\text { Atlanta analysts of } \\
\text { professional } \\
\text { organizations }\end{array}$ & Financial condition & $\begin{array}{l}\text { Municipal } \\
\text { annual reports }\end{array}$ & & $\begin{array}{l}\text { Evaluation of determinants of } \\
\text { disclosure quality in governmental } \\
\text { financial reports using a simple or } \\
\text { compound indexing procedure }\end{array}$ \\
\hline $\begin{array}{l}\text { Giroux } \\
(1989)\end{array}$ & A sample of US cities & $\begin{array}{l}\text { Level of compliance of financial } \\
\text { reporting disclosures with } \\
\text { authority requirements }\end{array}$ & & $\begin{array}{l}\text { Pension and } \\
\text { employment } \\
\text { benefit }\end{array}$ & \\
\hline $\begin{array}{l}\text { Guo et al. } \\
(2009)\end{array}$ & $\begin{array}{l}\text { Sample of Florida } \\
\text { cities with a } \\
\text { population over } \\
50,000\end{array}$ & $\begin{array}{l}\text { Socioeconomic factors, housing } \\
\text { market related factors, fiscal } \\
\text { health and heuristic tools }\end{array}$ & $\begin{array}{l}\text { Management } \\
\text { discussion and } \\
\text { analysis }\end{array}$ & & \\
\hline $\begin{array}{l}\text { Fischer et al. } \\
(2010)\end{array}$ & $\begin{array}{l}\text { Sample of public and } \\
\text { private institutions of } \\
\text { higher education in } \\
\text { the US }\end{array}$ & $\begin{array}{l}\text { Comparison of key differences } \\
\text { in the recognition and } \\
\text { presentation of financial } \\
\text { information between FASB and } \\
\text { GASB standards }\end{array}$ & $\begin{array}{l}\text { Financial } \\
\text { statements }\end{array}$ & & \\
\hline $\begin{array}{l}\text { Blanco et al. } \\
(2011)\end{array}$ & $\begin{array}{l}\text { Canadian local } \\
\text { governments }\end{array}$ & Financial information & $\begin{array}{l}\text { Financial } \\
\text { statements, } \\
\text { audited } \\
\text { financial } \\
\text { statements } \\
\end{array}$ & & \\
\hline $\begin{array}{l}\text { Vermeer et } \\
\text { al. (2012) }\end{array}$ & $\begin{array}{l}\text { US local } \\
\text { governments }\end{array}$ & $\begin{array}{l}\text { Level of compliance of financial } \\
\text { statement disclosures with the } \\
\text { requirements under GASBS No. } \\
27\end{array}$ & & Pension plans & $\begin{array}{l}\text { Factors that explain a government's } \\
\text { propensity to include disclosure } \\
\text { concerning pension plans }\end{array}$ \\
\hline $\begin{array}{l}\text { Kaur and } \\
\text { Arora (2013) }\end{array}$ & $\begin{array}{l}\text { A sample of public } \\
\text { and private sector } \\
\text { Indian companies }\end{array}$ & $\begin{array}{l}\text { Financial and non-financial } \\
\text { items }\end{array}$ & Annual reports & & $\begin{array}{l}\text { The influence of company } \\
\text { attributes on corporate disclosure }\end{array}$ \\
\hline $\begin{array}{l}\text { Bunget et al. } \\
\text { (2014) }\end{array}$ & $\begin{array}{l}\text { Annual reports of } \\
\text { Romanian } \\
\text { municipalities }\end{array}$ & $\begin{array}{l}\text { Compliance with the } \\
\text { requirements of disclosure } \\
\text { demanded by accounting rules } \\
\text { on intangible assets held by } \\
\text { IPSASB }\end{array}$ & & $\begin{array}{l}\text { Intangible } \\
\text { assets }\end{array}$ & \\
\hline $\begin{array}{l}\text { de Deus and } \\
\text { de } \\
\text { Mendonça } \\
(2015) \\
\end{array}$ & $\begin{array}{l}\text { A sample of } \\
\text { Eurozone Countries }\end{array}$ & $\begin{array}{l}\text { Accuracy of government budget } \\
\text { balance fiscal forecast }\end{array}$ & $\begin{array}{l}\text { Balance } \\
\text { forecast errors }\end{array}$ & & $\begin{array}{l}\text { Analysis on the determinant factors } \\
\text { of government budget balance } \\
\text { forecast error }\end{array}$ \\
\hline $\begin{array}{l}\text { Allini et al. } \\
\text { (2016) }\end{array}$ & $\begin{array}{l}\text { Italian state owned } \\
\text { enterprises }\end{array}$ & Risk disclosure & $\begin{array}{l}\text { Management } \\
\text { Commentary }\end{array}$ & & $\begin{array}{l}\text { Relationship between specific } \\
\text { board characteristics and the risk } \\
\text { disclosure }\end{array}$ \\
\hline
\end{tabular}

While highlighting that environmental accounting studies concerned with the mandated disclosure are not as numerous as those that deal with voluntary disclosure, Freedman and Park (2013) investigate the mandated disclosure made by public electric utility firms participating in the Regional Greenhouse Gas Initiative (RGGI). This study focuses on two reports (10k and 20-F), which must be submitted annually to the Securities and Exchange Commission to determine what public firms report on RGGI and climate change.

To recapitulate, the findings of these studies emphasize the relevance of the disclosure of non-financial information. This is coherent with a more general trend observed in the public sector literature, in which scholars are going beyond the traditional financial/accounting information provided by public sector entities. Transparency and accountability concern not only the use of financial resources, but also the attention paid to environmental issues. In other words, public sector entities are increasingly required to be socially responsible 
(Fox, Ward, \& Howard, 2002).

As to IC disclosure, we find only one highly cited paper (Schneider \& Samkin, 2008), which is the first study to make use of an IC disclosure index constructed through a participatory stakeholder consultation process. This index focuses on the extent and the quality of the disclosure of IC in the annual reports of a sample of local government authorities in New Zealand. IC has attracted increasing attention from scholars and practitioners in the public sector in the last decade (Guthrie \& Dumay, 2015). However, it should be critically observed that studies regarding the measurement of disclosure of traditional IC components are still in their embryonic stage, especially with regard to local governments (Dumay, Guthrie, \& Puntillo, 2015; Garlatti, Massaro, Dumay, \& Zanin, 2014; Massaro et al., 2015). Thus, future research should focus on this under-investigated theme.

\subsubsection{Accountability, Governance and Performance Measurement}

In terms of accountability and governance (C4), we found an old, highly cited paper (Herzlinger, 1996), which stresses the need for the disclosure of nonfinancial quantitative information as a way of determining if governmental and non-profit organizations are fulfilling their missions. The author provides an example of how analysis might work in practice by applying the ideas retrospectively to the bankruptcy of Orange County, California, as well as by showing how it might have been avoided.

Bisogno et al. (2014) analyse the disclosure of information by Italian universities through their websites. The paper investigates the main areas of interest of the principal stakeholders (such as research, teaching activities, governance, financial information, social responsibility, interactivity with users and so on). This study also includes analysis of disclosure determinants to investigate the reasons why some universities disclose more or less information than others. Considering the growing relevance of universities' websites as a primary tool for the disclosure of information, we would encourage scholars to investigate this field further, also comparing different contexts.

Hooks et al. (2014) identify stakeholders' expectations of the information to be conveyed in Malaysian local authorities' reports and develop an index of best practice performance in reporting to improve the transparency and public accountability of local authorities. Krambia-Kapardis (2014) investigates whether countries with enacted legislation on electoral accountability issues (such as conflicts of interest, revolving doors, asset disclosure, lobbying, immunity, political party funding and codes of conduct for politicians) have lower corruption perceptions than countries without such legislation on these variables. Indeed, public sector corruption is currently one of the problems most discussed in the world and several countries are planning to introduce legislation on whistle-blowing (Bisogno, Nota, \& Ianulardo, 2017) to fight this phenomenon. Therefore, we would encourage scholars to investigate these issues in relation to the information provided by public sector entities, examining if there is a relationship between the DQ level and corruption.

With regard to performance measurement (C6), Sahel et al. (2015) present an innovative quality improvement intervention called the "Quality Contest" (QC), targeting health centres, hospitals and health district offices in Morocco and combining quality measurement with structure ranking, performance disclosure and reward systems.

\subsubsection{Other}

The last category (C7: other) consists of five articles covering a wide range of subjects; we include them in this residual category because we could not find any significant similarities to create a new category.

An interesting paper (Joseph \& Taplin, 2011) provides a methodological contribution to disclosure studies in the public sector. Content analysis of disclosure abundance and disclosure indices (disclosure occurrence) are popular methods for measuring the extent of disclosure. However, few past studies concerning private sector companies have compared the two approaches empirically or have used empirical evidence to justify the use of one method over the other. Joseph and Taplin (2011) provide insights into the differences in results produced by measuring sustainability disclosures using the occurrence (or presence or richness) of items disclosed and the abundance (or volume) of disclosed items. Specifically, this was one of the first studies to use local government websites to compare regression results using disclosure abundance and disclosure occurrence. More specifically, it seems that most hypothesized independent variables explain variation in the richness or variety of disclosures (disclosure occurrence), but not the abundance (or total volume) of disclosures.

$\mathrm{Yu}$ (2014) focuses on the relationship between provincial environmental performance and the e-governance levels of provincial environmental protection department websites in China, while Deaconu and Nistor (2014) analyse the degree of convergence between the International Public Sector Accounting Standard (IPSAS) and International Valuation Standards (IVS), which are designed for financial reporting, particularly in the public 
sector. Finally, Abu Bakar and Saleh (2015) review the development of research undertaken in understanding the factors influencing public sector disclosure and a recent article (Araújo \& Tejedo-Romero, 2016) explores if there are specific factors or determinants that affect the level of transparency in Spanish municipalities.

\subsection{Research Methods}

The research methods criterion (D), adapted from Guthrie et al. (2012), includes five attributes. The first three relate to studies that are empirical in nature, these being: D1: case/field study/interviews; D2: content analysis (CA)/historical analysis (e.g. Abd Rahman et al., 2011; Joseph \& Taplin, 2011); D3: surveys/questionnaire/other empirical (e.g., Coy \& Dixon, 2004; Coy et al., 1993; Giroux, 1989; Gordon et al., 2002; Lynch, 2010; Robbins $\&$ Austin, 1986). The next two attributes are normative in nature and include commentary/normative/policy (D4) (Herzlinger, 1996) and literature review (D5) (Abu Bakar \& Saleh, 2015). It is noteworthy that the classification of several articles was not particularly easy as they adopted more than one research method. In such cases, the article was coded based on the dominant research method used for primary data analysis (e.g. Bunget et al., 2014; Coy \& Dixon, 2004; Hooks et al., 2014; Sahel et al., 2015).

The results show that the research method most commonly employed for investigating DQ measurement in the public sector is survey/questionnaire/other empirical (D3), numbering twenty studies. For example, Coy et al. (1993) and Coy and Dixon (2004) propose and test a new weighted index (the public accountability index [PAI]) to evaluate the quality of service performance reporting by a sample of New Zealand universities. Gordon et al. (2002) provide insights into the financial disclosure by US higher education institutions, both public and private. Similarly, Lynch (2010) tests a new type of environmental disclosure index to examine environmental voluntary disclosure practices within the annual reports produced by a sample of Australian state government departments.

Eight studies adopt CA/historical analysis. For instance, Abd Rahman et al. (2011) provide an empirical CA to determine the CSR disclosure practices of a sample of government-linked companies. Similarly, Joseph and Taplin (2011) provide a methodological contribution related to disclosure studies in the public sector. They offer insights into differences in results produced by measuring sustainability disclosures for a sample of Malaysian local authority websites using CA (disclosure abundance) and disclosure indices (disclosure occurrence).

However, it should be observed that in the case of IC disclosure, Dumay and Cai (2015) have highlighted the potential risk of CA methodology. They argue that "the popularity of CA as a research method for investigating IC disclosure has become so great that at times the research methodology 'drives the research questions' as opposed to the "research questions driving the methodology".

Abu Bakar and Saleh's (2015) paper, while being the first literature review in the field, does not rely on a predefined set of rules, as in the case of a structured literature review. Therefore, according to Massaro et al. (2016), it can be classified as a narrative review, with a lower degree of reliability compared to a structured literature review. Finally, the case/field study/interview category has no papers and an old, highly cited paper is normative in nature (Herzlinger, 1996).

Considering the growing relevance of ICT in the today's world, we would argue that future studies should adopt quantitative approaches and mixed methods to relate the DQ level and socio-economic implications of policies aimed at improving transparency and fighting corruption.

\subsection{DQ Measurement in Public Sector Frameworks and Models}

Regarding the criterion "DQ measurement in public sector frameworks and models" (E), in line with Guthrie et al. (2012) and Dumay and Garanina (2013), we code the articles as follows: E1: none proposed; E2: applies or considers previous; E3: proposes a new.

The results show that 16 papers (53.3\% of the sample) use or consider a previous framework (Abd Rahman et al., 2011; Joseph \& Taplin, 2011), 10 papers (33.3\% of the sample) propose new frameworks (e.g. Coy \& Dixon, 2004; Yu, 2014) and only 4 (13.33\% of the sample) do not use any framework (e.g. Herzlinger, 1996).

Analysing the evolution before 2010, we note that some of the highly cited articles propose some new weighted indices to evaluate the quality of service performance reporting provided by universities (e.g. Coy \& Dixon, 2004; Gordon et al., 2002). Other highly cited scholars propose some composite measures to investigate the level of CSR and its determinants (e.g. Abd Rahman et al., 2011), voluntary environmental disclosure practices (e.g. Lynch, 2010) or the quality of IC disclosure (Schneider \& Samkin, 2008).

In addition, over the last two years, none of the papers has proposed a new model; researchers tend increasingly to apply the existing frameworks in their research (e.g. Allini et al., 2016; Araújo \& Tejedo-Romero, 2016; Keerasuntonpong et al., 2015; Sahel et al., 2015). 


\section{Future Research Directions}

This study has investigated DQ measurement in the public sector context through a structured literature review methodology to offer a critical overview of state of the art on this topic, at the same time highlighting a future research agenda. Therefore, this section aims to discuss the main findings emerging from the study, answering the research question: "What is the future of DQ measurement within the public sector?"

More concretely, according to Denyer and Tranfield (2006), the aim is to provide a research synthesis (Stanley, 2001), surfing among the different approaches adopted and trying to put "together findings from a number of empirical studies in some coherent way" (Tranfield et al., 2003, p. 214).

A first point emerging from our findings is that most authors contribute just once to the body of literature in this field; therefore, we have not identified some specific authors who produce the majority of the papers. This result could mean that barriers to entry to the academic discourse are low and/or that scholars have mainly focused on DQ measurement within the private sector, in particular examining healthy firms, while there is a lack of attention concerning this topic within public sector entities. Moreover, the low barriers to entry, in turn, could imply that authors not specialized in the field can move from the general topic of DQ measurement or even from other research fields when publishing. Therefore, it is worth noting that authors who are more consistent within this topic, publishing more than one paper, can easily acquire a higher specialization and visibility, as shown by the analysis of the impact of the articles.

A second point emerging from this review is that most articles are written by academics (26), while only four are co-written by academics and practitioners (e.g. Blanco et al., 2011; Sahel et al., 2015). However, closing the gap between academic research on DQ measurement in the public sector and the accounting profession/practitioners is needed because, as Guthrie, Burrit, and Evans (2011, p. 9) argue, "There needs to be more communication and coordination between practitioners, policy makers and academic researchers" in general. Accordingly, this could be a future path to follow.

A third relevant point concerns the limited international comparisons. According to Nomaler, Frenken, and Heimeriks (2013, p. 966) "international collaboration can stimulate dialogue between scholars of different background and therefore lead to unique outcomes and more creative solutions". Moreover, "internationally co-authored papers are known to have more citation impact than nationally co-authored papers, on average". Our findings show that international collaborations among authors are quite high (11 papers within the sample analysed); even if there is international collaboration, articles developing international comparisons are scarce. Furthermore, as a related implication emerging from this review, it is worth observing the high concentration of previous studies in some areas, while others seem to be under-investigated. Accordingly, future research could investigate and compare more than one context to fill this gap and highlight the potential role played by DQ in relation to factors such as the socio-economic conditions of different countries.

Another relevant issue emerging from this study concerns the evolution of the research in this field over the years. The oldest papers regarding the financial compliance of financial reporting disclosures with authoritative requirements or the disclosure of financial information in mandatory documents date back to the 1980s (e.g. Giroux, 1989; Robbins \& Austin, 1986). Therefore, focusing on the development of research in the more recent period (from the year 2010 onwards), it is interesting to note the move towards looking at non-financial reporting, as well as website disclosure. More specifically, our findings show an increasing interest in non-financial reporting, particularly with regard to social and environmental reporting. Some examples are Abd Rahman et al. (2011), Lynch (2010) and Yu (2014), whose studies focus on CSR disclosure practices and voluntary environmental disclosure. In addition, a new reporting medium, which includes Internet reporting, is also attracting the attention of researchers (e.g. Araújo \& Tejedo-Romero, 2016; Bisogno et al., 2014). This phenomenon appears to be consistent with the recent development and growth of more advanced technologies. This trend is coherent with the objective pursued by public sector entities to improve the dialogue with their citizens, experiencing new tools such as integrated reporting (Guthrie et al., 2017) and so-called popular reporting (Cohen et al., 2017). Accordingly, a future research agenda could concern the disclosure level of these tools, as well as the role of social media in the level of disclosure of public sector entities, considering their relevant role in the current digital democratic era.

We would also encourage scholars to investigate the relationship between the information provided by public sector entities, the level of transparency and the corruption phenomenon. More broadly, we would argue for researchers expanding their perspective by considering the implications of DQ issues for society.

Finally, we consider the limitations of this study: as interpretive research, our findings are limited to the studies selected in this review and their interpretation. Even though an SLR methodology is more robust and reliable 
than a traditional review, other research applying the same methodology might interpret the results differently.

\section{References}

Alvesson, M., \& Deetz, S. (2000). Doing Critical Management Research. London, England: Sage.

Bisogno, M., Nota, G., \& Ianulardo, M. (2017). Transparency, accountability and fighting corruption: A model on whistle-blowing processes. In Cuadrado-Ballesteros, B. \& Garcia-Sanchez, M. I. (Eds.), Local governments in the digital era: looking for accountability (pp. 171-185). New York, Nova Science Publisher's, Inc.

Broadbent, J., \& Guthrie, J. (1992). Changes in the public sector: A review of recent "alternative" accounting research. Accounting, Auditing \& Accountability Journal, 5(2), 3-31. https://doi.org/10.1108/09513579210011835

Broadbent, J., \& Guthrie, J. (2008). Public sector to public services: 20 years of "contextual" accounting research. Accounting, Auditing \& Accountability Journal, 21(2), 129-169. https://doi.org/10.1108/09513570810854383

Cohen, S., Mamakou, X. J., \& Karatzimas, S. (2017). IT-enhanced popular reports: Analyzing citizen preferences. Government Information Quarterly, 34(2), 283-295. https://doi.org/10.1016/j.giq.2017.04.003

Denyer, D., \& Tranfield, D. (2006). Using qualitative research synthesis to build an actionable knowledge base, Management Decision, 44(2), 213-227. https:// doi.org/10.1108/00251740610650201

Dixon-Woods, M. (2011). Systematic reviews and qualitative methods. In D. Silverman (Ed.), Qualitative Research. Issues of Theory, Method and Practice (pp. 331-346). London, England: Sage.

Dumay, J. (2014). 15 years of the journal of intellectual capital and counting: A manifesto for transformational IC research. Journal of Intellectual Capital, 15(1), 2-37. https:// doi.org/10.1108/JIC-09-2013-0098

Dumay, J., \& Cai, L. (2015). Using content analysis as a research methodology for investigating intellectual capital disclosure: A critique. Journal of Intellectual Capital, 16(1), 121-155. https://doi.org/10.1108/JIC-04-2014-0043

Dumay, J., \& Garanina, T. (2013). Intellectual capital research: A critical examination of the third stage. Journal of Intellectual Capital, 14(1), 10-25. https:// doi.org/10.1108/14691931311288995

Dumay, J., Bernardi, C., Guthrie, J., \& Demartini, P. (2016). Integrated reporting: A structured literature review. Accounting Forum, 40(3), 166-185. https://doi.org/10.1016/j.accfor.2016.06.001

Dumay, J., Guthrie, J., \& Puntillo, P. (2015). IC and public sector: A structured literature review. Journal of Intellectual Capital, 16(2), 267-284. https://doi.org/10.1108/ JIC-02-2015-0014

Garlatti, A., Massaro, M., Dumay, J., \& Zanin, L. (2014). Intellectual Capital and Knowledge Management within the public sector. A systematic literature review and future developments. Proceedings of the 11th International Conference on Intellectual Capital, Knowledge Management and Organisational Learning (pp. 175-184).

Guthrie, J., \& Dumay, J. (2015). New frontiers in the use of intellectual capital in the public sector. Journal of Intellectual Capital, 16(2), 258-266. https://doi.org/10.1108/ JIC-02-2015-0017

Guthrie, J., Burritt R., \& Evans, E. (2011). The relationship between academic accounting research and professional practice. In Guthrie, J., Burritt R., \& Evans E. (Eds.), Bridging the gap between academic accounting research and professional practice (pp. 9-20). Chapter retriewed from https://www.icaew.com/

Guthrie, J., Manes-Rossi, F., \& Levy Orelli, R. (2017). Integrated Reporting and Integrated Thinking in Italian Public Sector Organisations. Meditari Accountancy Research, forthcoming. Doi.org/10.1108/MEDAR-06-2017-0155

Guthrie, J., Ricceri, F., \& Dumay, J. (2012). Reflections and projections: A decade of intellectual capital accounting research. The British Accounting Review, 44(2), 68-82. http://dx.doi.org/10.1016/j.bar.2012.03.004

Krippendorff, K. (2012). Content analysis: An introduction to its methodology. Los Angeles, US: Sage.

Massaro, M., Dumay, J., \& Garlatti, A. (2015). Public sector knowledge management: a structured literature review. Journal of Knowledge Management, 19(3), 530-558. https://doi.org/10.1108/JKM-11-2014-0466

Massaro, M., Dumay, J., \& Guthrie, J. (2016). On the shoulders of giants: undertaking a structured literature 
review in accounting. Accounting, Auditing \& Accountability Journal, 29(5), 767-801. https://doi.org/10.1108/AAAJ-01-2015-1939

Murias, P., de Miguel, J.C. and Rodríguez, D. (2008). A composite indicator for university quality assessment: the case of Spanish higher education system? Social Indicator Research, 89(1), 129-146. https://doi.org/10.1007/s11205-007-9226-z

Nomaler, Ö., Frenken, K., \& Heimeriks, G. (2013). Do more distant collaborations have more citation impact? Journal of Informetrics, 7(4), 966-971. http://dx.doi.org/10.1016/j.joi.2013.10.001

Paramewaran, R. and Glowacka, A. (1995). University image: an information processing perspective. Journal of Marketing for Higher Education, 6(2), 41-56. http://dx.doi.org/10.1300/J050v06n02_04

Petticrew, M., \& Roberts, H. (2008). Systematic Reviews in the Social Sciences: A Practical Guide. Kindle edition. Wiley-Blackwell, Oxford.Stanley, T. (2001). Wheat from chaff: meta-analysis as quantitative literature review. Journal of Economic Perspectives, 15(3), 131-150. https://doi.org/10.1257/jep.15.3.131

Steccolini, I. (2004), Is the Annual Report an Accountability Medium? An Empirical Investigation into Italian Local Governments. Financial Accountability \& Management, 20(3), 327-350. https://doi.org/10.1111/j.0267-4424.2004.00389.x

Tranfield, D., Denyer, D., \& Smart, P. (2003). Towards a methodology for developing evidence-informed management knowledge by means of systematic review. British Journal of Management, 14(3), 207-222. https://doi.org/10.1111/1467-8551.00375

\section{Notes}

Note 1. For the purpose of this paper CPY $=$ Citations (2016 - Year of publication). This is the same formula now used in Harzing's Publish or Perish software (http://www.harzing.com/pop.htm).

\section{Appendix}

\section{DQ Measurement in Public Sector publications reviewed (1986-2016)}

Abd Rahman, N. H. W., Mohamed Zain, M., \& Yahaya Al-Haj, N. H. Y. (2011). CSR Disclosures and Its Determinants: Evidence from Malaysian Government Link Companies. Social Responsibility Journal, 7(2), 181-201. http://dx.doi.org/10.1108/17471111111141486

Abu Bakar, N. B., \& Saleh Z. (2015). Review of Literature on Factors Influencing Public Sector Disclosure: The Way Forward. Asian Journal of Business \& Accounting 8(2), 155-184. Retrieved from https://ajba.um.edu.my/index.php/AJBA/article/view/2717

Allini, A., Manes Rossi, F., \& Hussainey, K. (2016). The board's role in risk disclosure: an exploratory study of Italian listed state-owned enterprises. Public Money \& Management, 36(2), 113-120. http://dx.doi.org/10.1080/09540962.2016.1118935

Araújo, J. F., \& Tejedo-Romero, F. (2016). Local Government Transparency Index: Determinants of Municipalities' Rankings. International Journal of Public Sector Management, 29(4), 327-347. http://dx.doi.org/10.1108/IJPSM-11-2015-0199

Bisogno, M., Citro, F., \& Tommasetti, A. (2014). Disclosure of University Websites. Evidence from Italian Data. Global Business and Economics Review, 16(4), 452-71. http://dx.doi.org/10.1504/GBER.2014.065365

Blanco, H., Lennard, J. \& Lamontagne, S. (2011). Annual Reporting and Accountability by Municipalities in Canada: An Empirical Investigation. Accounting Perspectives, 10(3), 195-224. http://dx.doi.org/10.1111/j.1911-3838.2011.00024.x.

Bunget, O. C., Blidisel, R. G., Feleaga, L., \& Popa, I. E. (2014). Empirical Study of Intangible Assets in Romanian $\quad$ Municipalities. Ekonomie a Management, 17(3), 136-51. http://dx.doi.org/10.15240/tul/001/2014-3-011

Condie, J., Dunmore, V.P. \& Dunstan, K. (2013). Cognitive Affordances in Performance reporting: The Case of Service Performance in New Zealand Universities. Pacific Accounting Review, 25(2), 165-187. http://dx.doi.org/10.1108/PAR-12-2012-0062

Corina, J., \& Taplin, R., (2011). The Measurement of Sustainability Disclosure: Abundance versus Occurrence. 
Accounting Forum, 35(1), 19-31. http://dx.doi.org/10.1016/j.accfor.2010.11.002

Coy, D., \& Dixon, K. (2004). The Public Accountability Index: Crafting a Parametric Disclosure Index for Annual Reports. British Accounting Review, 36(1), 79-106. http://dx.doi.org/10.1016/j.bar.2003.10.003

Coy, D., Tower, G., \& Dixon, K. (1993). Quantifying the Quality of Tertiary Education Annual Reports. Accounting \& Finance, 33(2), 121-30.

De Deus, J.D.B.V., \& de Mendonça, H.F., (2015). Empirical Evidence on Fiscal Forecasting in Eurozone Countries. Journal of Economic Studies, 42(5), 838-60. http://dx.doi.org/10.1108/JES-04-2014-0054

Deaconu, A., \& Nistor C.S. (2014). Valuation in the Public Sector. Reference Factor in a Credible and Fair Administration. Transylvanian Review of Administrative Sciences, 10(43), 85-102.

Fischer, M., Gordon, T.P., \& Kraut M.A. (2010). Meeting User Information Needs: The Impact of Major Changes in FASB and GASB Standards on Financial Reporting by Colleges and Universities. Journal of Accounting and Public Policy, 29(4), 374-399. http://dx.doi.org/10.1016/j.jaccpubpol.2010.03.001

Freedman, M., \& Park, J.D. (2014). Mandated Climate Change Disclosures by Firms Participating in the Regional Greenhouse Gas Initiative. Social and Environmental Accountability Journal, 34(1), 29-44. http://dx.doi.org/10.1080/0969160X.2013.852988

Giroux, G. (1989). Political Interests and Governmental Accounting Disclosure. Journal of Accounting \& Public Policy, 8(3), 199-217.

Gordon, T., Fischer, M., Malone, D., \& Tower, G. (2002). A comparative empirical examination of extent of disclosure by private and public colleges and universities in the United States. Journal of Accounting and Public Policy, 21(3), 235-275.

Guo, H., Fink D., \& Frank, H. (2009). Disclosure Quality of Management Discussion and Analysis (MD\&A): Evidence from Large Florida Cities. Municipal Finance Journal, 30(3), 53-72.

Herzlinger, R. E. (1996).Can Public Trust in Nonprofits Governments Be Restored? Harvard Business Review, 74(2), 97-107.

Hooks, J., S. Tooley, S., \& Basnan, N., (2012). An Index of Best Practice Performance Reporting for Malaysian Local Authorities. Journal of Applied Accounting Research, 13(3), 270-283. http://dx.doi.org/10.1108/09675421211281335

Kaur, N., \& Arora, R.S., (2013). An Empirical Investigation of the Association between Company Attributes and Disclosure Score of Indian Companies. Indian Journal of Finance, 7(9), 44-53.

Keerasuntonpong, P., Dunstan, K. \& Khanna, B. (2015). Factors Influencing Disclosures of Statements of Service Performance of New Zealand Local Authorities. Pacific Accounting Review, 27(3), 304-328. http://dx.doi.org/10.1108/PAR-02-2014-0005

Krambia-Kapardis, M. (2014). Perception of Political Corruption as a Function of Legislation. Journal of Financial Crime, 21(1), 44-55. http://dx.doi.org/10.1108/JFC-04-2013-0025

Lynch, B. (2010). An Examination of Environmental Reporting by Australian State Government Departments. Accounting Forum, 34(1), 32-45. http://dx.doi.org/10.1016/j.accfor.2009.11.001

Mansi, M. (2014). Sustainable Procurement Disclosure Practices in Central Public Sector Enterprises: Evidence from India. Journal of Purchasing and Supply Management, 21(2), 125-37. http://dx.doi.org/10.1016/j.pursup.2014.12.002

Robbins, W. A., \& Austin, K.R., (1986). Disclosure Quality in Governmental Financial Reports: An Assessment of the Appropriateness of a Compound Measure. Journal of Accounting Research, 24(2), 412-421.

Sahel, A., DeBrouwere, V., Bruno Dujardin, V. B., Kegels, G., Belkaab, N., \& Belghiti, A.A. (2015) Implementing a Nationwide Quality Improvement Approach in Health Services. Leadership in Health Services, 28(1), 24-34. http://dx.doi.org/10.1108/LHS-04-2014-0042

Schneider, A., \& Samkin, G. (2008). Intellectual Capital Reporting by the New Zealand Local Government Sector. Journal of Intellectual Capital, 9(3), 456-86. http://dx.doi.org/10.1108/14691930810892036

Vermeer, T. E., Styles, A. K., \& Patton, T. K. (2012). Do Local Governments Present Required Disclosures for Defined Benefit Pension Plans? Journal of Accounting \& Public Policy, 31(1), 44-68. http://dx.doi.org/10.1016/j.jaccpubpol.2011.04.002 
Yu, Y. (2015). An Empirical Analysis of the Relationship between Environmental Performance and Sustainable E-Governance in China. Technological Forecasting and Social Change, 96, 71-78. http://dx.doi.org/10.1016/j.techfore.2014.10.009

\section{Copyrights}

Copyright for this article is retained by the author(s), with first publication rights granted to the journal.

This is an open-access article distributed under the terms and conditions of the Creative Commons Attribution license (http://creativecommons.org/licenses/by/4.0/). 